13. These include a project to understand the origins of the life in the Universe involving biologists, chemists and astrophysicists, and one to tackle global health, which would bring together experts in areas such as infectious disease, mental health, diagnostics, policy, economics, law and bioethics.

A second goal is to reform undergraduate education. Summers thinks that all undergraduates need to gain a more extensive grounding in modern scientific subjects such as genomics, so that they emerge as well versed in science as they are in the humanities. $\mathrm{He}$ also wants to see them all spend some time studying abroad. Both priorities are reflected in an undergraduate curriculum review currently under way at the university.

A third intention of Summers, which he doesn't spell out quite so explicitly, is to transform the collection of traditionally autonomous faculties into a single, more coherent university. He has done this partly by introducing more scrutiny of each school's budget and tenure appointments. Summers argues that this kind of supervision can save the university money, ensure that academic standards are consistent across the institution, and help the university to address academic questions that fall beyond the scope of any individual faculty.

\section{Foundation stones}

All of these ambitions will, Summers believes, be furthered by the successful transformation of Allston into a vast, new academic centre. "The very substantial physical resources we have available in Allston will allow us to define the Harvard of the twenty-first century," he says.

In a letter to the Harvard community on 21 October 2003, Summers outlined his ideas for renovating the 200 fragmented acres at Allston. He expects new science and technology facilities to form the heart of the new campus, alongside a new home for the School of Public Health and the Graduate School of Education, new student housing and an array of shops, museums and other attractions to ensure that students and staff alike flock to the site.

The plans for Allston aren't yet complete. But the occupants of the first scientific labs there, probably including the new institute for stem-cell research, are expected to be announced in the first half of this year.

Many academics, particularly those whose favourite projects are likely to benefit directly, are enthused by Summers' plans, and have embraced the opportunity to consider cross-cutting fields. "No past president has given us the freedom to think in those terms before," says chemist Greg Verdine, who has been involved in an initiative that combines chemistry and biology to, for example, try to adjust the action of biological molecules.

But Allston, which embodies much of Summers' broader schemes for the university, has also become a focal point for criticism particularly among scientists at Harvard.

Problems flared up in the Faculty of Arts and Sciences in October 2003, when staff members were alerted to the release of Summers' letter in an e-mail that they received only a few hours before they were due to discuss it in a faculty meeting. In this meeting and subsequent ones, many staff members expressed doubts about the plan. "To say there is faculty concern and lack of enthusiasm is a massive understatement," says one staff member.

\section{Critical point}

Critics raise three main concerns. First, they say that Summers and the administration failed to discuss adequately the best course for the university's development, and that such consultations that did take place were purely cosmetic. "As far as I can tell, Larry and a bunch of other high-level officials met, and then Larry just decided what he wanted to say," says astrophysics professor Alyssa Goodman.

Second, critics question whether an aggressive physical expansion is either desirable or necessary. They argue that the university could fulfil many of its needs for interdisciplinary work by careful expansion and collaboration within Cambridge, and point out that small departments can be intimate and advantageous for collaboration. "Being big doesn't necessarily mean being good," says Feldman.

Third, they are uneasy about the isolation of the new campus. Its location, perhaps a 20-30-minute commute from the Cambridge campus, could divide rather than unite the scientific community, they say, interfering with the interdisciplinary collaborations it is supposed to nurture. They also worry that it could isolate science from the university's heart at Harvard Yard. "I think creating a science ghetto is a bad idea," says Goodman.

Summers and Hyman are unmoved by the criticisms. They claim that initial dissension over the Allston plans has dissipated as members of staff have had the chance to participate in the planning process, and get fired up about the opportunities there. "If you'd listened to the discussion that took place at a recent faculty meeting, it had a relatively different tone from that at the meeting a year ago," Summers observes.

The two men also brush off the suggestion that expansion at Harvard is unnecessary. Growth and change, they say, is the only way to ensure that the university is able to fully engage in emerging areas of research 50 years from now. "The danger to Harvard is that people run the risk of becoming too comfortable and complacent because it is so successful," says Hyman.

And they urge the critics to engage in the renovation process, instead of opposing it. "I've asked people to focus their energy on what they want to do and how I can help them do it - and not to focus as much energy on what they think other people should not be allowed to do,"Summers says.

Whether academics choose to follow or fight Summers' they do seem to be learning to live with his approach. Some say that they find his decisiveness refreshing - and preferable to the agonizingly slow and consultative process that sometimes dogged decisionmaking in the past. "Every time you make a big, bold decision you're going to piss people off - but presidents have to do that," says professor of psychology Marc Hauser.

Nevertheless, in a place that thrives on academic debate, Summers' combative approach will continue to send ripples of dissent through the quads and corridors. And Summers has yet to impress everyone that his way of working is suited to the venerable institution. "You don't run Harvard the way you run the Department of the Treasury," says history of science professor Everett Mendelsohn. Helen Pearson works in New York for Nature's online news team. 